\title{
SEX PREFERENCE ON CHILD AND MODERN CONTRACEPTION USE IN FERTILE AGE WOMEN IN INDONESIA (ANALYSIS OF IDHS 2017)
}

\author{
Deby Novita Sari \\ Masters in Population and Employment Economics, Faculty of Economics and Business, University of Indonesia, 16424 \\ Depok City, West Java, Indonesia \\ Corresponding Author: Deby Novita Sari \\ E-mail: deby.novita@ui.ac.id
}

\begin{abstract}
Generally, this study aims to describe the characacteristics of modern contraception users in fertile age women in Indonesia. Specifically, this study will examine the effect of the children's sex preferences on the use of modern contraception. Furthermore, the control variables used are age, education taken by the mothers, mothers' working status, marital status, Family Planning Field Officer (Petugas Lapangan Keluarga Berencana/PLKB) visits, and internet usage. The data used in this study was taken from the results of the Indonesian Demographic and Health Survey (IDHS) 2017. Data analysis was using descriptive and inferential analysis. Descriptive analysis used is in the form of a single table and a cross-tabulation, while the inferential analysis used is binary logistic regression. Based on the descriptive analysis results, it can be concluded that $79.35 \%$ of fertile age women (15-49 years old) in Indonesia do not have particular sex preference on their children. Moreover, the inferential analysis results with a significance level by $1 \%$, it appears that child's sex preference will reduce the chance of modern contraception use. Women's age, the number of children that safely delivered, marital status, and FPFO visits are having the positive effect on the modern contraception use, while the residential area, education taken, and internet usage are negatively affect the modern contraception use.
\end{abstract}

Keywords: contraception, sex preference, modern contraception, family planning, internet

\begin{abstract}
ABSTRAK
Secara umum, penelitian ini bertujuan untuk mendeskripsikan karakteristik pengguna kontrasepsi modern pada wanita usia subur di Indonesia. Secara khusus, penelitian ini akan melihat pengaruh preferensi jenis kelamin anak terhadap penggunaan kontrasepsi modern di Indonesia. Sedangkan variabel kontrol yang digunakan adalah usia, pendidikan wanita, status bekerja wanita, status perkawinan, kunjungan PLKB, dan penggunaan internet. Data yang digunakan dalam penelitian ini berasal dari hasil Survei Demografi dan Kesehatan Indonesia (SDKI) tahun 2017. Metode analisis yang digunakan dalam penelitian ini adalah analisis deskriptif dan inferensial. Analisis deskriptif yang digunakan berupa tabel tunggal maupun tabulasi silang, sedangkan analisis inferensial yang digunakan berupa regresi logistik biner. Berdasarkan hasil analisis deskriptif, telihat bahwa sebesar 79,35 persen wanita usia subur (15-49 tahun) di Indonesia tidak memiliki preferensi jenis kelamin anak tertentu. Berdasarkan hasil analisis inferensial, dengan tingkat signifikansi satu persen, terlihat bahwa adanya preferensi jenis kelamin anak akan menurunkan peluang wanita untuk menggunakan kontrasepsi modern. Usia wanita, jumlah anak masih hidup, status perkawinan, dan kunjungan petugas lapangan KB berpengaruh positif terhadap penggunaan kontrasepsi modern, sedangkan wilayah tempat tinggal, pendidikan wanita, dan penggunaan internet berpengaruh negatif terhadap penggunaan kontrasepsi modern pada wanita.
\end{abstract}

Kata kunci: kontrasepsi, preferensi jenis kelamin, kontrasepsi modern, keluarga berencana, internet

\section{INTRODUCTION}

After stagnating at 2.6 for ten years (20022012), Indonesia's total fertility rate (TFR) according to the 2017 IDHS has fallen to 2.4. The reduction in TFR is important because it relates to the demographic bonus that is currently being experienced by Indonesia
(Nulhakim and Samosir, 2018). When birth rates are low, families will have fewer children. If the number of children owned is less, parents can allocate their income to improve children's quality, for example by providing better education and health, so that the quality of human resources will be more qualified in the future (Samosir, 2013). 
At the micro-level, the use of contraception can improve maternal health, reduce child mortality, reduce abortion, and improve family welfare. While at the macro-level, the use of contraception can control population growth, improve infrastructure, and reduce the expense of government budget (Nonvignon and Novignon, 2014).

The measure used to see the number of contraception use among fertile age couples is the Contraception Prevalence Rate or CPR (Cristie and Budiantara, 2015). CPR is negatively related to TFR (Samosir, 2013). In the 1970s, the TFR rate in Indonesia was still very high by 5.605 (Central Bureau of Statistics, 2011). In regards to the massive and structured family planning program introduced by the government through the National Family Planning Coordinating Board, TFR managed to drop to 3,326 in twenty years (Adioetomo and Pardede, 2018). The success of family planning in reducing the TFR can be seen from the achievements of CPR which was almost $0 \%$ in 1960 to $49.7 \%$ in 1991 (Central Bureau of Statistics, 2011). After 2002/2003, the increase in CPR was slowing down. CPR only rose about 3 percent from $60.3 \%$ in $2002 / 2003$ to $63.6 \%$ in 2017 (National Board of Population and Family Planning, 2018). Though the government set a target of increasing CPR to 66\% in 2019 (Ministry of National Development Planning/National Development Planning Agency, 2014).

There are several hindrances for women in using contraception. Septalia and Puspitasari (2016) found that the material costs and side effects had a significant effect on the choice of certain contraceptive method. Other research also proved that the low level of education and limited family planning service facilities can affect the use of certain contraception method (in this case the IUD) (Purbaningrum, Hariastuti, and Wibowo, 2019). Fitria's research found that not all couples who want to delay or prevent pregnancy are using contraception (unmet need), the reasons are commonly because of the fear of side effects, worry about physical changes, worry about reduced milk production, not supported by her husband, and worry about health problems (Ainina, 2018). Furthermore, previous unpleasant experiences of contraception can also be the reason for a woman to not using the same contraception for the second time (Destiwi, 2019).
Kinuthia explained that there are four factors influence the choice of contraception in women, where these factors are interrelated and often determine a woman's decision to choose a particular method of contraception (Mbugua, 2013). These four factors are partner, socioeconomic, socio-demographic, and sociocultural factors. A child's gender preference is one of the cultural factors that influence the use of contraception. Couples who do not have children of the same sex according to their preferences will be reluctant to use contraception (Najafi-Sharjabad et al., 2013). They will continue to give birth and delay using contraception until the desired sex composition of the child matches their preferences even though the number exceeds the number of children desired (Trisnani, 2016; Putri, 2018). This can increase fertility rates and consequently, targets to reduce fertility rates as expected by the government will be increasingly difficult to achieve. Another impact that can be caused is increasing the risk of maternal and child mortality due to maternal deaths and birth spacing that is too close to increase the number of children born.

Research on the sex preferences of children has been carried out in many South Asian countries known as child preference (Hoq, 2019; Channon, 2015). Hoq's research in Bangladesh found that boys are valued more than girls since there is a perception formed in the community that boys are more capable to make money for the family, have greater employment opportunities later, and guarantee welfare in the retirement days (Hoq, 2019). Raising boys is valued as an investment value because it can be used as a source of family income when working, while spending on girls is considered as consumption because when they are adults, they will be taken by their husbands (Hoq, 2019). As a result, the CPR of women who only have daughters is lower than the CPR of women who already have sons (Hoq, 2019). Women will decide to use contraception to prevent or even stop their birth when the composition of the child they have is following what is desired and usually this happens when they have a son (Hoq, 2019).

Another study was carried out by Channon in South Asia. The study found that when a woman already has a child with the desired sex composition, then she will tend to stop giving birth and start to use contraception (Channon, 2015). The use of contraception will increase 
along with the addition of the number of children and the number of boys the couple has (Hoq, 2019).

In Indonesia, little research has been conducted on the relationship between sex preference and contraception use. Trisnani (2016) researched the relationship of sex composition to the use of modern contraception by using the Intercensal Population Survey 2015 data. However, the research was only conducted in three provinces which were considered to represent the three existing kinship relationships, namely in West Sumatra to represent matrilineal kinship, in North Sumatra to represent patrilineal kinship, and in Central Java representing bilateral kinship. The limitations of the study are not including the ideal number of children wanted, environmental factors such as the role of family planning field officers, and the influence of the media on contraceptive use. Besides, the research unit in this study is a mother who has one or more children. Even though the mother might not use contraception because she still wants to have more children, not because of the sex of the previous child. Other research on contraceptive use has been carried out by Nulhakim and Samosir (2018) regarding factors that influence contraceptive use in Indonesia using InterCensus Population Survey 2015 data. The main variable used in the study is internet use. However, the study did not include a variable in the composition of a child's sex against contraception use not because of the sex of the previous child. Other research on contraception use has been carried out by Nulhakim and Samosir (2018) regarding factors that influence contraception use in Indonesia using the Intercensal Population Survey 2015 data. The main variable used in the study is internet use. However, the study did not include a variable in the composition of a child's sex against contraception use not because of the sex of the previous child. Other research on contraceptive use has been carried out by Nulhakim and Samosir (2018) regarding factors that influence contraception use in Indonesia using InterCensus Population Survey 2015 data. The main variable used in the study is internet use. However, the study did not include a variable in the composition of a child's sex against contraception use.

However, research on this subject is still rarely carried out in Southeast Asian countries, especially in Indonesia. This study aims to describe the characteristics of users of modern contraception in Indonesia and explain the influence of child sex preferences and other control variables with the use of modern contraception infertile age women. The control variables used in this study are women's age, education, working status, marital status, Family Planning Field Officer visits, and internet usage.

\section{METHODS}

The data source used in this study is the data from Indonesian Demographic and Health Survey 2017 (IDHS). The IDHS is a national survey conducted to obtain data and information on births, deaths, family planning, and health in Indonesia. The IDHS 2017 is implemented in all provinces in Indonesia and covers 47,963 households living in urban and rural areas. There are three types of respondents in the IDHS 2017: fertile age women aged 15-49 years old, married men aged 15-54 years old, and young men aged 15-24 years. The sample unit of this study was fertile age women who were not pregnant during the interview. After going through the data cleaning process, the samples in this study were 33,729 women.

The dependent variable in this study is modern contraception use. Status of contraception use refers to the modern contraception method that is being used at the time of the interview (current use of contraception). The definition of modern contraception in this study is the same as the IDHS 2017 concept, which includes IntraUterine Device (IUD), implants, female sterilization or female surgery methods (tubectomy), and male sterilization or male surgery methods (vasectomy), condom, family planning injection, birth control pills, emergency contraception, and the lactation amenorrhea method (MAL).

The main independent variable used is sex preference. According to Nugraha (2016), sex preference can be measured in two ways: through the ideal composition of the desired child and the composition of the child currently owned. In this study, sex preference was approached by using the question of the ideal number of children desired by sex. If the ideal number of boys is greater than girls, then it is given code 1 or has a male preference. If on the contrary it is given code 2 or a female preference. Whereas if the ideal number of girls 
is equal to boys, it is given a code of 0 or without any sex preference. The control variables used in this study are the women's age and the residential area.

The analytical method in this study uses descriptive analysis in the form of a single table and cross-tabulation and inferential analysis using binary logistic regression.

\section{RESULT}

\section{Descriptive Analysis}

Table 1. Sample Distribution according to Characteristics

\begin{tabular}{|c|c|c|}
\hline Characteristics & $\mathbf{n}$ & $\%$ \\
\hline \multicolumn{3}{|c|}{ Contraception Use } \\
\hline Yes & 20,396 & 60.47 \\
\hline No & 13,333 & 39.53 \\
\hline \multicolumn{3}{|l|}{ Sex Preferences } \\
\hline Male & 3,260 & 9.66 \\
\hline Female & 3,704 & 10,98 \\
\hline No Preferences & 26,765 & 79.35 \\
\hline \multicolumn{3}{|l|}{ Age } \\
\hline$<25$ & 4,329 & 12.83 \\
\hline $25-35$ & 11,711 & 34.72 \\
\hline $35+$ & 17,689 & 52.45 \\
\hline \multicolumn{3}{|l|}{ Residential Area } \\
\hline Rural & 17,407 & 51.61 \\
\hline Urban & 16,322 & 48.39 \\
\hline \multicolumn{3}{|c|}{ The number of alive children } \\
\hline$<2$ & 104,747 & 31.86 \\
\hline 2 & 12,534 & 37.16 \\
\hline $3+$ & 10,448 & 30.98 \\
\hline \multicolumn{3}{|c|}{ Women's Education } \\
\hline$\leq$ Basic School & 12,308 & 36.49 \\
\hline Middle School & 17,375 & 51.51 \\
\hline$\geq$ High School & 4,046 & 12.00 \\
\hline \multicolumn{3}{|c|}{ Women's Working Status } \\
\hline Work & 19,1 & 56.63 \\
\hline Does not work & 14,629 & 43.37 \\
\hline \multicolumn{3}{|l|}{ Marital status } \\
\hline Marry & 33,548 & 99.46 \\
\hline Living together & 181 & 0.54 \\
\hline \multicolumn{3}{|c|}{ Family Planning Field Officer Visit } \\
\hline Yes & 1,161 & 3.44 \\
\hline No & 32,568 & 96.56 \\
\hline \multicolumn{3}{|l|}{ Internet use } \\
\hline Yes & 12,383 & 36.71 \\
\hline No & 21,346 & 63.29 \\
\hline
\end{tabular}

Source: IDHS 2017, processed
The distribution of sample characteristics can be seen in table 1. Based on the table it can be seen that most of the samples use modern contraception $(60.47 \%)$, do not have any gender preference $(79.35 \%)$, aged 35 years and above $(52.45 \%)$, living in rural areas $(51.61 \%)$, have two children $(37.16 \%$ ), have a junior high school education $(51.51 \%)$, worked during the past week $(56.53 \%)$, are married $(99,46 \%)$, do not get a visit from Family Planning Field Officer in the last 12 months $(96.56 \%)$, and do not use the internet in the last 12 months $(63.29 \%)$.

Table 2. Cross Tabulation of Sample Characteristics according to Use of Contraception

\begin{tabular}{|c|c|c|c|}
\hline \multirow{2}{*}{ Characteristics } & \multicolumn{3}{|c|}{ Use of contraception } \\
\hline & Yes & Not & Total \\
\hline \multicolumn{4}{|l|}{ Sex Preferences } \\
\hline Male & 56.77 & 43.23 & 100.00 \\
\hline Female & 57.94 & 42.06 & 100.00 \\
\hline No Preferences & 61.27 & 38.73 & 100.00 \\
\hline \multicolumn{4}{|l|}{ Age } \\
\hline$<25$ & 62.95 & 37.05 & 100.00 \\
\hline $25-35$ & 63.94 & 36.06 & 100.00 \\
\hline $35+$ & 57.52 & 42.48 & 100.00 \\
\hline \multicolumn{4}{|l|}{ Residential Area } \\
\hline Rural & 62.60 & 37.40 & 100.00 \\
\hline Urban & 58.20 & 41.80 & 100.00 \\
\hline \multicolumn{4}{|c|}{ The number of alive children } \\
\hline$<2$ & 45.51 & 54.49 & 100.00 \\
\hline 2 & 69.83 & 30.17 & 100.00 \\
\hline $3+$ & 64.63 & 35.37 & 100.00 \\
\hline \multicolumn{4}{|c|}{ Women's Education } \\
\hline$\leq$ Basic School & 62.46 & 37.54 & 100.00 \\
\hline Midd & 61.68 & 38.32 & 100.00 \\
\hline$\geq$ High School & 49.22 & 50.78 & 100.00 \\
\hline \multicolumn{4}{|c|}{ Women's Working Status } \\
\hline Work & 62.67 & 37.33 & 100.00 \\
\hline Does not work & 58.79 & 41.21 & 100.00 \\
\hline \multicolumn{4}{|l|}{ Marital status } \\
\hline Marry & 60.60 & 39.40 & 100.00 \\
\hline Living together & 36.82 & 63.18 & 100.00 \\
\hline \multicolumn{4}{|c|}{ Family Planning Field Officer Visit } \\
\hline Yes & 66.82 & 33.18 & 100.00 \\
\hline No & 60.24 & 39.76 & 100.00 \\
\hline \multicolumn{4}{|l|}{ Internet use } \\
\hline Yes & 56.26 & 43.74 & 100.00 \\
\hline No & 62.91 & 37.09 & 100.00 \\
\hline
\end{tabular}

Source: IDHS 2017, processed 
The cross-tabulation results of independent variables with the dependent variable can be seen in table 2. The largest percentage of women who use modern contraception are those who do not have a particular sex preference $(61.27 \%)$. The more older the women's age, the smaller the percentage of women who do not use contraception. If you look at the status of the residential area, it is seen that modern contraception is more widely used by women in rural areas than in urban areas. When women have less than two children, more than half of women do not use contraception, but when they already have two or more children, more than half of women use modern contraception. Examining the highest education completed, modern contraception use decreases as women's education higher. The use of modern contraception in working women is higher than in women who do not work. More married women use contraception, while for those who cohabitate, a greater percentage of women do not use contraception. Although not much different, the percentage of women who use contraception is greater in those who have been visited by family planning officers than those who have not. The use of contraception is higher in women who have never accessed the internet than those who have ever accessed the internet.

The percentage of women who use contraception is greater in those who have been visited by family planning officers than those who have not. The use of contraception is higher in women who have never accessed the internet than those who have ever accessed the internet. the percentage of women who use contraception is greater in those who have been visited by family planning officers than those who have not. The use of contraception is higher in women who have never accessed the internet than those who have ever accessed the internet.

The percentage of women who use modern contraception is greater in women who do not have certain sex preferences, aged over 35 years, living in rural areas, having two or more children, having education until elementary school and below, working, being married, having received visits from the Family Planning Field Officer, and never access the internet.

\section{Inferential Analysis}

Table 3 shows the test results using binary logistic regression. From the nine independent variables, eight variables were proven to have a significant effect on contraception use. The women's working status variable does not have a significant effect on the significance level of $5 \%$.

Sex preference has been shown to have a significant effect on the use of modern contraception for fertile age women in Indonesia. At $1 \%$ level of significance, the chances of women who do not have any sex preferences are higher than women who do, to use modern contraception. The tendency of women to use contraception who have boys' preference is lower than women who do not have any sex preference with an odds ratio of 0.871 times. Whereas for women with girl preference, 0.868 times less chance to use modern contraception than women without any sex preference.

When looking at age, it appears that a woman's tendency to use contraception decreases with age. The opportunity for women under the age of 25 to use modern contraception is 3.304 times higher than for women aged 35 years and above. While the chance of women aged 25-35 years to use contraception is 1.982 times higher to use modern contraception than women aged over 35 years.

Another variable that has a significant effect on the use of modern contraception is the residential area. The chance of women living in urban areas to use modern contraception is 0.936 times lower than that of women living in rural areas. According to the number of alive children, it can be seen that the chance of women with two or more children to use modern contraception is higher than women with less than two children.

For women with junior high school education, there were no significant differences in the use of modern contraception with women with an elementary school education or below. However, for women who have completed high school and above, it is seen that the tendency of women to use contraception is 0.763 times lower than for women who have completed primary school and below.

When viewed according to working status, with a p-value of 0.056 it can be said that with 
Table 3. Parameter Estimation, Significance, and Odd Ratio of the Binary Logistic Regression Model

\begin{tabular}{|c|c|c|c|}
\hline Variable & Parameter Estimation & Sig & Odds Ratio \\
\hline \multicolumn{4}{|l|}{ Sex Preferences } \\
\hline Male & $-0.224 * * *$ & 0.000 & 0.799 \\
\hline Female & $-0.167 * * *$ & 0.000 & 0.846 \\
\hline No Preferences (ref) & - & - & - \\
\hline \multicolumn{4}{|l|}{ Age } \\
\hline$<25$ & 1.236 *** & 0.000 & 3.442 \\
\hline $25-35$ & $0.684 * * *$ & 0.000 & 1.982 \\
\hline $35+($ ref $)$ & - & - & - \\
\hline \multicolumn{4}{|l|}{ Residential Area } \\
\hline Rural (ref) & - & - & - \\
\hline Urban & $-0.095 * * *$ & 0.000 & 0.910 \\
\hline \multicolumn{4}{|c|}{ The number of alive children } \\
\hline$<2$ (ref) & - & - & - \\
\hline 2 & $1.356^{* * *}$ & 0.000 & 3.881 \\
\hline $3+$ & $1.271 * * *$ & 0.000 & 3.566 \\
\hline \multicolumn{4}{|l|}{ Women's Education } \\
\hline$\leq$ Basic School (ref) & - & - & - \\
\hline Middle School & 0.015 & 0.592 & 1.015 \\
\hline$\geq$ High School & $-0.325 * * *$ & 0.000 & 0.722 \\
\hline \multicolumn{4}{|c|}{ Women's Working Status } \\
\hline Working & -0.046 & 0.056 & 0.955 \\
\hline Not Working (ref) & - & - & - \\
\hline \multicolumn{4}{|l|}{ Marital status } \\
\hline Marry & $1.163 * * *$ & 0.000 & 3.199 \\
\hline Living Together (ref) & - & - & - \\
\hline \multicolumn{4}{|c|}{ Family Planning Field Officer Visit } \\
\hline Yes & $0.196^{* * *}$ & 0.003 & 1.216 \\
\hline No (ref) & - & - & - \\
\hline \multicolumn{4}{|l|}{ Internet use } \\
\hline Yes & $-0.129 * * *$ & 0.000 & 0.879 \\
\hline No (ref) & - & - & - \\
\hline
\end{tabular}

Source: IDHS 2017, processed

Note: $* * *$ Significant at $\mathrm{p}<0.01 * *$ Significant at $\mathrm{p}<0.05$

a 5\% of significance level, there is not enough evidence to say that there are significant differences between women who work and women who do not work on modern contraception use. However, looking at the estimated parameters that are negative, it can be said that the tendency of women who work to use modern contraception is lower than women who do not work.

Marital status of a woman will increase her chances of using contraception. Married women are 2.689 times tend to use modern contraception than women who cohabitate.

Women who in the last 12 months ever received a visit from a Family Planning Field
Officer have 1.206 times higher tendency to use modern contraception than women who had never received a visit from the Family Planning Field Officer.

Based on the experience of using the internet, it appears that the tendency of women who have used the internet is lower than women who have never had the internet with an opportunity ratio of 0.913 times.

\section{DISCUSSION}

The results of this study indicate that $79.35 \%$ of women in Indonesia do not have any sex preferences. This means that they assume 
that the value of having son and daughter is the same. This is in line with Nugraha's study which stated that the majority of women in Indonesia do not have certain sex preference (Nugraha, 2016). In south Asian countries, child preference can be seen from the desired sex ratio at birth which can illustrate how big a boy is more desirable than a girl (Channon, 2015). Based on the study, the highest desired sex ratio at birth was in Pakistan and Nepal, at 133 and lowest in Bangladesh, at 111.

According to modern contraception use, the tendency of women to use contraception is reduced if the women have a particular child sex preference. The results of this study are in line with Hoq's research on child preference in Bangladesh. In the society with a strong child preference, the value of boys is higher than girls because they think that boys are more capable to make money for the family than girls. Therefore, the CPR of women who do not have son is lower than the CPR of women who already have son (Hoq, 2019). In North Sumatra, women who have only girls are 0.885 times less likely to use contraception than those who have only boys (Trisnani, 2016). Couples who have a particular sex preference for the child will be a barrier for the couple to use contraception (Najafi-Sharjabad et al., 2013).

Younger women have a greater tendency to use modern contraception than older women. This contradicts Fitrianingsih's research which states that the older a person is, the wiser it is to choose contraception, so there is more chance to use contraception, especially in the long term (Fitrianingsih and Melaniani, 2017). However, this is in line with the research of Wang and Malick who found that as a woman gets older the woman's tendency to use contraception is lower because they feel the chances of getting pregnant are getting smaller (Wang and Mallick, 2019; Ekoriano and Novita, 2018; Rahayu, Utomo and Mcdonald, 2009).

Opportunities for women in rural areas to use modern contraception are greater than women in urban areas. In line with Trisnani's research in Central Java, the use of contraception in rural areas is greater than in urban areas. This may be due to family planning programs that are still oriented in rural areas so that family planning programs are more ingrained in rural areas than in urban areas (Trisnani, 2016).

The more children they have, the greater the chance for women to use contraception. In line with previous research that women who have more children will prefer to control or regulate their births than women who have fewer children (Miradora, 2017; Nonvignon and Novignon, 2014). Women's motivation to use contraception increases with the number of children they have because the number of children they want has been reached (Abate and Tareke, 2019).

For women with education level reaching high school and above, their tendency to use modern contraception is lower than for women who have completed primary school and below. This means that the more educated a woman will reduce her tendency to use modern contraception. In line with research conducted by Ekoriano and Novita that the biggest contraceptive users are women with low education (Ekoriano and Novita, 2018). Whereas Fitrianingsih and Melaniani's research in Surabaya found that there were no differences in the use of contraception between women with high and low education (Fitrianingsih and Melaniani, 2017).

Women who are married are more likely to use modern contraception than women who are living together with a partner. In line with research Ameyaw et. al in Ghana that contraception is more widely used by women who are married than women who are not married (Ameyaw et al., 2017). This may be due to cultural and religious factors that are strongly embedded in Indonesian society that the legal partners are those who are married. With the status of marriage, women can more easily and comfortably plan their families with family planning than women who only live together (Tilahun, 2014).

Woman ever visited by Family Planning Field Officer over the past 12 months has a greater tendency to use modern contraception than women who have never visited a Family Planning Field Officer. This is in line with Oktaviana's research that mothers who receive Family Planning Field Officer visits can consult directly with officers about what contraception is used. This can increase women's knowledge about family planning (Oktaviana, 2015).

The tendency to use modern contraception is lower in women who have used the internet in the last 12 months than in women who have never used the internet. In contrast to the research of Nulhakim and Samosir which states that internet use has a positive effect on the use of modern contraception (Nulhakim and 
Samosir, 2018). This may be because women who access the internet can access more information about contraception, including side effects that may be caused (Picavet, Van der Leest, and Wijsen, 2011). Worrying about side effects, such as worrying that it will cause certain diseases, worrying about being unsuitable for certain contraception, or even becoming infertile are the main barriers for women to use contraception (Ochako et al., 2015). According to the IDHS 2017, 22.7\% of women do not use contraception because of family planning methods, such as incompatibility, fear of side effects, discomfort when using, fear of weight gaining or losing, etc (National Board of Population and Family Planning, 2018). Furthermore, women accessing the internet can find more alternative options for managing births besides using modern contraception (Nulhakim and Samosir, 2018). For example, by using traditional contraception such as interrupted intercourse, periodic abstinence, and other traditional methods.

\section{CONCLUSIONS AND SUGGESTIONS}

\section{Conclusion}

Most women in Indonesia do not have any child sex preferences. Based on the results of binary logistic regression testing, the child's gender preference has a significant effect on the use of modern contraception in women. Women who have certain sex preferences have a lower tendency to use modern contraception than women who do not have any sex preference.

Other control variables that have a positive influence on the use of modern contraception are age, the number of alive children, marital status, and Family Planning Field Officer visits. While the variables that have a negative influence on contraceptive use are the women's residential area,education, and internet usage. The variable work status of women does not significantly influence the use of modern contraception at a significance level of 5\%.

\section{Suggestion}

Based on the findings that a child's gender preference can negatively influence the use of modern contraception, it can be suggested that the government through the National Family Planning Coordinating Board can improve effective communication, information, and education (IEC) so that information about the benefits of using contraception, no matter what sex the child has can reach the community. In addition, the National Family Planning Coordinating Board's promotion of "boys and girls are the same" needs to be disseminated and promoted in various places so that the sex preferences of children who still exist in the community can be reduced.

Lower number of contraception use among educated women living in urban areas indicates the need to disseminate information to various groups that are easily accessible to the community. Socialization regarding various types of contraception, how the side effects are, and how to overcome them also needs to be done by competent officers. This is done to prevent confusion about the dangers and side effects of contraception that can cause women to be afraid to use it.

Given the important role of family planning officers in increasing women's opportunities to use contraception, the National Family Planning Coordinating Board can further enhance the participation of the Family Planning Field Officer to educate women about contraception.

\section{REFERENCES}

Abate, M.G., Tareke, A.A., 2019. Individual and Community Level Associates of Contraceptive Use in Ethiopia: A Multilevel Mixed Effects Analysis. Archives of Public Health, 77 (1), pp. 1-12.

Adioetomo, S.M., and Pardede, E.L., 2018. Bonus Demografi dan jendela Peluang Meletakkan Dasar Pembangunan Manusia. In: Memetik Bonus Demografi, Membangun Manusia Sejak Dini.

Ainina, N., 2018. Analisis Faktor yang Memengaruhi Kebutuhan Ber-KB dengan Pendekatan Social Cognitive Theory (Studi di Kecamatan Genteng Surabaya). Jurnal Biometrika dan Kependudukan. 7 (1), pp.1-10.

Ameyaw, E.K., Appiah, F., Agbesi, C.S., and Kannor, P., 2017. Contraceptive Use in Ghana: What about Women Empowerment. Advances in Sexual Medicine. 7 (1), pp.44-64.

Central Bureau of Statistics, 2011. Fertilitas Penduduk Indonesia: Hasil Sensus Penduduk 2010. Jakarta.

National Board of Population and Family 
Planning, 2018. Survei Demografi dan Kesehatan Indonesia 2017. Jakarta.

Cristie, D., and Budiantara, I.N., 2015. FaktorFaktor yang Mempengaruhi Contraceptive Prevalence Rate (CPR). Jurnal Sains dan Seni ITS. 4 (1), pp. 97-102.

Channon, M.D., 2015. Son Preference, Parity Progression and Contraceptive Use in South Asia. Population Horizons. 12 (1), pp. 24-36.

Destiwi, M., 2019. Penggunaan Metode Kontrasepsi Susuk KB di Jawa Timur (Analisis Data SUSENAS 2015). Jurnal Biometrika dan Kependudukan. 8 (1), pp. 32-41.

Ekoriano, M., and Novita, F., 2018. The Dinamika Pemakaian Kontrasepsi Modern di Indonesia (Analisis Data Susenas 2015). Jurnal Kependudukan Indonesia. 13 (1), pp.27-38.

Fitrianingsih, A.D.R., and Melaniani, S., 2017. Faktor Sosio Demografi yang Memengaruhi Pemilihan Metode Kontrasepsi. Jurnal Biometrika dan Kependudukan. 5 (1), pp.10.

Hoq, M.N., 2019. Effects of Son Preference on Contraceptive Use in Bangladesh. Kesmas: National Public Health Journal. 14 (1), pp. 21-28.

Ministry of National Development/National Development Planning Agency, 2014. Rencana Pembangunan Jangka Menengah Nasional 2015-2019. Jakarta.

Mbugua, K.K., 2013. Factors Influencing Uptake Of Bilateral Tubal Ligation Among Women Who Have Completed Family Size In Central And Eastern Provinces. University of Nairobi.

Miradora, K.G., 2017. Determinants of Modern Contraceptive Use in the Philippines Determinants of Modern Contraceptive Use in the Philippines. International Journal of Policy Studies. 8 (1), pp. 45-68.

Najafi-Sharjabad, F., Yahya, S.Z.S., Rahman, H.A, Hanafiah, M., and Manaf, R.A., 2013. Barriers of modern Contraceptive Practices among Asian Women: A Mini Literature Review. Global Journal of Health Science. 5 (5), pp.181-192.

Nonvignon, J., and Novignon, J., 2014. Trend and Determinants of Contraceptive Use among Women of Reproductive Age in Ghana. African Population Studies. 28 (2), pp. 956-967.

Nugraha, A., 2016. The Effect of Sex
Preference to The Desire to Have Another Children in Indonesia. pp.318-323.

Nulhakim, I., and Samosir, O.B., 2018. The Effects of Internet Access on Contraceptive Use in Indonesia (Intercensal Population Survey Data Analysis of 2015). In: Proceedings of the 2nd International Conference on Indonesian Economy and Development (ICIED 2017).

Ochako, R., Mbondo, M., Aloo, S., Kaimenyi, S., Thompson, R., Temmerman, M. and Kays, M., 2015. Barriers to modern contraceptive methods for uptake among young women in Kenya: A qualitative study Global Health. BMC Public Health, 15 (1), pp.1-9.

Oktaviana, W., 2015. Determinan Penggunaan Kontrasepsi oleh Wanita Berstatus Kawin di Daerah Perdesaan: Analisis Survei Demografi dan Kesehatan Indonesia (SDKI) Tahun 2012. pp.1-109.

Picavet, C., Van der Leest, L., and Wijsen, C., 2011. Contraceptive Decision-Making: Background and Outcomes of Contraceptive Methods. [Online]. Available at: https://www.rutgers.nl/sites/rutgersnl/files/ PDF/Contraceptive_Decisions_Reportdef.pdf.

Purbaningrum, P., Hariastuti, I. and Wibowo, A., 2019. Analisis Faktor Rendahnya Penggunaan Kontrasepsi Intra Uterine Device (IUD) di Jawa Timur 2015. Jurnal Biometrika dan Kependudukan. 8 (1), pp. 52-61.

Putri, Y.R., 2018. Fenomena Penggunaan Kontrasepsi di Indonesia Analisis Data Sekunder Indonesia Family Life Survey (IFLS 5) 2014/2015. 5.

Rahayu, R., Utomo, I., and Mcdonald, P., 2009. Contraceptive Use Patterns among Married Women in Indonesia. In: International Conference on Family Planning: Research and Best Practices. Uganda.

Samosir, O.B., 2013. Dasar-Dasar Demografi. 2nd ed. Jakarta: Salemba Empat.

Septalia, R. and Puspitasari, N., 2016. Faktor yang Memengaruhi Pemilihan Metode Kontrasepsi. Jurnal Biometrika dan Kependudukan. 5 (2), pp. 91-98.

Tilahun, T., 2014. Marital dynamics in family planning: the role of couple interaction in Jimma zone, Southwest Ethiopia Doctoral thesis submitted to the Faculty of Medicine and Health Sciences at Ghent University 
in. Ghent University.

Trisnani, D., 2016. Hubungan Antara Komposisi Jenis Kelamin Anak dengan Penggunaan Alat Kontrasepsi Morern di Provinsi Sumatra Utara, Sumatra Barat, dan Jawa Tengah (Analisis Data Supas 2015). Thesis. Universitas Indonesia.
Wang, W., and Mallick, L., 2019. Understanding the Relationship between Family Planning Methods Choices and Modern Contraceptive Use: An Analysis of Geographically Linked Population and Health Facilities Data in Haiti. BMJ Global Health, 4 (Suppl 5), p.e000765. 